\title{
Lee Wilson
}

Martial Arts and the Body Politic in Indonesia. Leiden: Brill, 2015, xiv + $244 \mathrm{pp}$.

[Verhandelingen van het Koninklijk Instituut voor Taal-, Land- en Volkenkunde, vol. 299 / Power and Place in Southeast Asia, vol. 7]. ISBN 9789004289352. Price: Euro 75.0o (hardback).

Anyone who follows Indonesian politics is familiar with the sight of militia groups at political rallies, demonstrations, and government celebrations. One aspect of these militia groups is that many of them practice some form of the Indonesian martial art called Pencak Silat. In this book, Lee Wilson explores this martial art and seeks to explain how Pencak Silat has 'figured so conspicuously in Indonesian society and political culture' (p. 3). In particular, he is interested in 'models of power that have informed the practice and propagation of Pencak Silat, and what that can tell us more generally about forms of political authority in Indonesia' (p. 3). He argues that the history of Pencak Silat both as a martial art and as a 'system of physical and spiritual cultivation' (p. 3 ) is intricately linked with the rise of the Indonesian state. Thus, according to Wilson, the study of Pencak Silat reveals as much about 'the forces driving Indonesian nationhood as it does the development of Pencak Silat as a national martial art' (p. 1).

He opens Chapter One with a description of the headquarters of the Indonesian Pencak Silat Association (IPSI), the government bureaucracy tasked with administrating this diverse martial art form. The reader becomes very familiar with IPSI over the course of the book, as a significant portion of the text is focused on its history and how it has attempted to standardize the practice of Pencak Silat across the archipelago. One of his major themes is how IPS I, particularly under Suharto's New Order, took a broad set of highly localized practices and attempted to use them as a tool for national integration. At times, it seems as though Wilson is writing a history of IPSI, a worthwhile topic in and of itself, rather than exploring the topic highlighted in the book's title. The chapter goes on to provide a history of Pencak Silat in Indonesia, looking at its role during the colonial period, the Indonesian Revolution, and at post-independence efforts to promote it as both an international sport and as a symbol of national heritage. Along the way Wilson provides an interesting examination of debates over the meaning and development of the idea of Indonesian national culture through the lens of Pencak Silat.

Chapter Two compares how Pencak Silat is taught in Sundanese communities in West Java with the way it taught by IPSI. This might be one of the more interesting chapters for those explicitly interested in martial arts as Wilson explores how Sundanese practitioners teach students and how students

(C) CHRISTOPHER R. DUNCAN, 2017 DOI: 10.1163/22134379-17301015 
learn and then implement the various movements. The next two chapters provide an interesting contrast between the traditional practice of Pencak Silat and issues of spiritual authority in West Java (Chapter Three) to how the sport has been administered by IPSI since the New Order period and is now intertwined with political and military patronage networks (Chapter Four). Chapter Five builds on this theme through an exploration of the spiritual facets of Pencak Silat, such as its focus on the esoteric practices of inner knowledge (ilmu batin) and invulnerability (ilmu kebal). Wilson notes that while these practices remain important in some localized versions of Pencak Silat, IP SI would prefer to marginalize them in their efforts to modernize the sport. The final chapter includes an examination of the links between Pencak Silat groups and the political and military elite in Jakarta both during the overthrow of Suharto, and continuing into the present.

At times, particularly in the conclusion to each chapter, the text gets weighed down with academic jargon, which seems at odds with the crisp writing style of the detailed historical and ethnographic accounts that make up the bulk of the work. Another minor critique of the book, one not unique to Wilson's work, is that the book, although ostensibly about Indonesia as a whole is rather Java-centric, with only a few brief mentions of Lombok and Sumatra. It left this reader wondering about the current and historical importance of Pencak Silat, or variants of it, in eastern Indonesia or elsewhere in the archipelago. These minor criticisms aside, the book will be valuable to those seeking to learn about the history of Pencak Silat as a sport in an independent Indonesia, about the history of IPSI, as well as those looking for readings on the concept of power in Indonesia and Southeast Asia. The introduction and parts of the final chapter provide innovative looks at theories of power in Southeast Asia and are a veritable primer on the subject.

\section{Christopher R. Duncan}

Rutgers University, Newark

chris.duncan@rutgers.edu 